Proceeding ICOGISS 2019

Page 275-286. ISBN: 978-602-6 988-75-1

Web Jurnal Online: jurnal.unmuhjember.ac.id

By: Andy Arya Maulana Wijaya; LM. Azhar Sa'ban; Sry Mayunita

Collaborative Governance To Evolve Smart City In Local Governments

\title{
COLLABORATIVE GOVERNANCE TO EVOLVE SMART CITY IN LOCAL GOVERNMENTS
}

\author{
Andy Arya Maulana Wijaya ${ }^{1}$, LM. Azhar Sa'ban ${ }^{2}$ dan Sry Mayunita ${ }^{3}$ \\ ${ }^{1}$ University Of Muhammadiyah Buton, South East Sulawesi, Indonesia. \\ ${ }^{2}$ University Of Muhammadiyah Buton, South East Sulawesi, Indonesia \\ ${ }^{3}$ University Of Muhammadiyah Buton, South East Sulawesi, Indonesia \\ Email: andy.arya@umbuton.ac.id./ Phone: +6285255320044
}

\begin{abstract}
The smart-city is innovation concept providing effective and efficient public services, through innovation and the use of information technology infrastructure. There needs to be a collaboration between local governments, private agencies, and other community groups to develop this concept. However, the collaboration model seems to be very rarely studied in smart city envolve in local government. This paper uses a descriptive qualitative method, with a positivist approach. The results of the study explained that the Government of Baubau City was developing an online application for Information Management and Documentation Officers, that application provides information about which a number of data on finance, market prices, spatial data, and other public information were presented to support government transparency. Besides having developed links that the public can access various information on policies, programs, news, government activities, including online-based reporting systems, including development planning program (MUSREMBANG) now can be online. It's just that the implementation process is still oriented to the local government, while the private sector and the community have not fully contributed so that this service has not been optimal in providing effective and efficient services. The biggest challenges in implementing this are limited human resources and telecommunications infrastructure that is not yet optimal.
\end{abstract}

Keywords: Collaborative Governance, Smart-city, Local Government

${ }^{1}$ Penulis Korespondensi 
Proceeding ICOGISS 2019

Page 275-286. ISBN: 978-602-6 988-75-1

Web Jurnal Online: jurnal.unmuhjember.ac.id

By: Andy Arya Maulana Wijaya; LM. Azhar Sa’ban; Sry Mayunita

Collaborative Governance To Evolve Smart City In Local Governments

\section{INTRODUCTION}

Changes in information technology are so fast, demanding public services that are also increasingly dynamic. This then has an impact on the demands of city government services to produce a more effective and efficient work process. The bureaucratic reform program cannot work alone. He needs support for application based on information technology (IT). The existence of the Smart-City concept becomes a catharsis in answering this issue. The development of a city into a smart city is in line with the government program through Bappenas, which has established an urban development roadmap in the 2015-2019 National Medium-Term Development Plan (RPJMN) (https://finance.detik.com, 2016).

The Smart City concept is defined as a city that is able to use HR, social capital, and modern telecommunications infrastructure to realize sustainable economic growth and high quality of life, with wise resource management through community-based government participation. The Smart City concept is expected to provide solutions to urban constraints in the field of public services. Such as the existence of transparency and public participation, public transportation, non-cash transactions, waste management, energy, security, and the provision of city data and information. This is coupled with the number of Indonesian internet users in 2017 ranked sixth, reaching 143.26 million internet users or netter (https://tirto.id, 2018).

The urgency of a city to implement smart city is to facilitate services for its people, but by staying adaptive to technological advancements. According to, Giffinger, et al. (2007) Smart City is a capability the local government to apply flexibility, transformability, synergy, and individuality. On the other hand, Chourabiet al. (2012) believe the effectiveness of "smart" cities as a strategy to reduce the problems generated by urbanites due to rapid population growth. Kanter, R. M., \& Litow (2009) examined the making of the smart city by utilizing the industrial potential of big cities. The study emphasizes the science aspects of intelligence by using technological infrastructure and cloud computing (Washburn, D.et.al, 2010). Or Dirks, S., Et al. (2010) which predict the transparency of information by making urban intelligence.

From several studies, there are various patterns and models that are adapted to the dynamics of each city. Several studies on the application of smart city, provide information about the phenomenon of this concept. For example, Bandung City is able to create public services, apparatus performance, citizen interaction, data disclosure. Then, the city of Surabaya is innovating in the electronic application of regional development and community services, besides that there is a need for regulation, as well as good cooperation among various parties who really want to promote smart cities as a form of public service to society (Suhendra, 2017).

The application is not always easy, in Sarifuddin's (2015) study, states that smart-city principles in the preparation of natural disaster early warning systems in the city of Semarang, require local values in the form of community knowledge about disasters and 
Proceeding ICOGISS 2019

Page 275-286. ISBN: 978-602-6 988-75-1

Web Jurnal Online: jurnal.unmuhjember.ac.id By: Andy Arya Maulana Wijaya; LM. Azhar Sa'ban; Sry Mayunita Collaborative Governance To Evolve Smart City In Local Governments

community-based early warning systems need to be accommodated as a form of bottom-up feedback. Local values can manifest as an embryo of intellectual capital reinforcement that must continue to be developed. Whereas in Malang City, the smart-city concept was implemented by making a breakthrough in the Digital Information Creativity and Creativity Award (AIKID) program, which finally stimulated each SKPD to have a site that was used to disseminate innovation, information and urban public services (Widodo, 2016).

Makassar City is the closest example of implementing the smart-city concept. Sombere and Smart-City are concepts that combine technological progress but are still balanced by the local strong character of a friendly society and its local identity. The variety of smart-city concepts enables the need for multi-party collaboration in its development. The main issue for applying this concept is that the response of each region will vary. Therefore, to solve these problems, integrative and collaborative governance is needed. The government can involve non-government stakeholders in making and implementing public policies (Ansell \& Gash, 2008). This was also expressed by Emerson and Nabatchi (2015) that collaborative governance includes partnerships between countries, the private sector, the community, and a combination of government and non-government such as public-private partnerships or private-social partnerships or co-management regimes.

Multi-stakeholder involvement in smart-city implementation in several cities indicates that this concept requires collaboration between local governments and various parties as public service providers. Including in the City of Baubau, which was developing this concept at the end of the year.

Figure 1. Collaborative Model

(Emerson and Nabatchi,

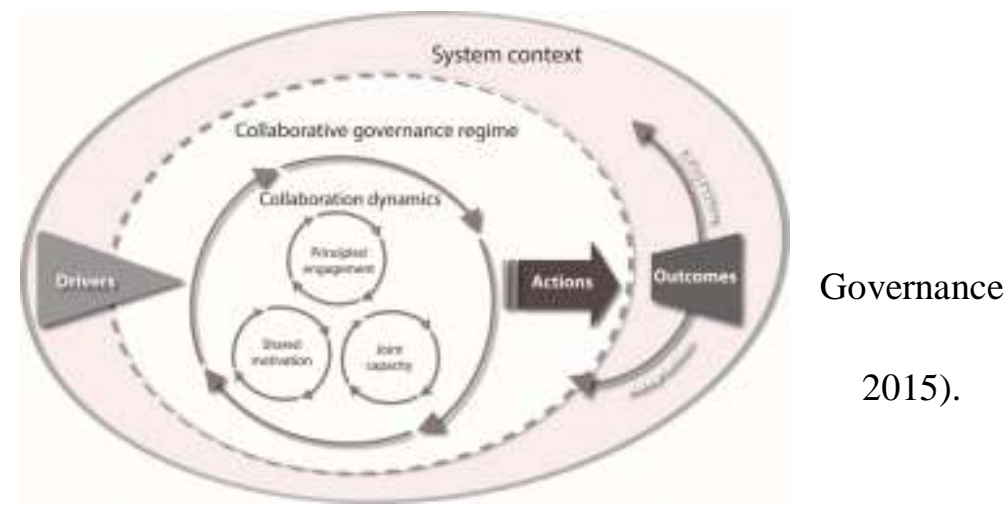

This research is also aimed at reviewing the development of the smart-city concept in the city of Baubau which in its implementation will certainly involve multi-stakeholders with their respective tasks and roles. Collaborative governance was chosen as a result that smart-city needs to be supported by strengthening the development supported by multi-stakeholder involvement in efforts to realize the City of Baubau as a Smart City. 
Proceeding ICOGISS 2019

Page 275-286. ISBN: 978-602-6 988-75-1

Web Jurnal Online: jurnal.unmuhjember.ac.id

By: Andy Arya Maulana Wijaya; LM. Azhar Sa’ban; Sry Mayunita Collaborative Governance To Evolve Smart City In Local Governments

\section{RESEARCH METHODS}

This research is descriptive qualitative research, using the case-study method or approach (Yin, 2009). This research was conducted by conducting interviews, observations and documentation studies that took place early in 2019. By taking research locations in Baubau City with a focus on the study of developing the concept of smart cities through the development of e-government content in the City of Baubau. Considerations for choosing this location are; One: intense interaction with the author, Dua: the development of the smart-city concept which is not only questioning the advancement of information technology but also the support of local resources that this combination is detected in the research location, Three: This is in line with the collaborative governance theory used in this study. Data collection was carried out by interviewing a number of informants, namely the Regional Development Planning Agency (Bappeda), Baubau City Communication and Information Agency (Diskominfo) and tracking related documents. Second, research is also carried out by conducting direct observation of the development of technology-based local government services, for example in development planning to the involvement of various creative communities in guarding regional policies. In processing data, researchers also do data reductions. as explained (Berg, 2001) this reduction of data is intended to direct attention to the focus of research needs, simplify, and change raw data into a more manageable form.

\section{RESULTS AND DISCUSSION}

\section{a. Transformation of the City of Baubau Towards a Smart City}

Before describing the process of the City of Baubau in the concept of smart cities, this research needs to provide a brief explanation of the profile of the City of Baubau. It is one of the cities located in Southeast Sulawesi province, with a land area of $221.00 \mathrm{~km} 2$, sea area reaching $30 \mathrm{~km} 2$ is a potential area for the development of sea transportation facilities and infrastructure. It consists of 8 (eight) sub-districts and 40 (forty) sub-districts, with a population of 261,454 people at the end of 2018. Regionally, the city of Baubau is located in the connecting area, which allows for rapid trade and services. This certainly can affect the social, economic, cultural and political conditions of the community.

In understanding these conditions, according to Emerson and Nabatchi (2015) that context systems are understood as collaborative governance initiated and developed in a layered context between politics, legal framework, socio-economic conditions, environment, and other influences. To understand this, it is important to understand the city of Baubau in its context to develop the concept of smart cities as demands for government services.

In 2015, Baubau City Government through Mayor Baubau Decree Number: 050/531 / IV / 2015 Concerning the Establishment of Smart-City Development Study Preparation Team in Baubau City in 2015. The Working Team in the Mayor's Decree was led by the Regional Secretary of Baubau City, but technical implementation by the Baubau City Development Planning Agency. With the existence of these regional legal instruments, the development of smart city became one of the designs for the development plan of Baubau 
Proceeding ICOGISS 2019

Page 275-286. ISBN: 978-602-6 988-75-1

Web Jurnal Online: jurnal.unmuhjember.ac.id

By: Andy Arya Maulana Wijaya; LM. Azhar Sa’ban; Sry Mayunita Collaborative Governance To Evolve Smart City In Local Governments

City. A number of supporting infrastructures are prepared and resource support begins to be collected.

Based on this decision in 2016, the Baubau City Bappeda mapped and prescribed priority areas to the Central Government. With that, the Ministry of Public Works and Public Housing, Baubau City became one of the regions in mapping "Compact and Smart Cities" with eight other cities throughout Indonesia. The most prominent issue in the designation of the title is its compact issue which is still very relevant to the situation in the Buton Palace Fortress, where the population will increase over time but does not eliminate the inheritance and cultural values. The innovation element by the community is very strong in influencing the assessment.

This is also supported by the learning process of the smart city concept by the Baubau City government, by learning about the application of smart cities to Kendari City. This process is as much an understanding of the concept of urban development in smart cities as 6 dimensions, namely smart economy, intelligent mobility, intelligent environment, intelligent society, intelligent life, and finally smart government.

Other preparations were made through the Baubau City Communication and Information Agency (Diskominfo) through a collaborative program (PKS) memorandum of understanding (MoU) with the Makassar City Government. The activity carried out in December 2018 intends to present the use of information technology in electronic government-based work systems (e-government) in the Application of Smart Cities in the City of Baubau that can facilitate public services. The discussion directly involves the two heads of regional offices, namely H .Irus Taufiq Saidi, S.Kom, M.Sc and staff representing the Baubau City Government, and Drs. Ramli Hajiali, M.Sc and Najran SP representing the Makassar City Government.

The next development was Focus Group Discussion (FGD) in the formulation of the direction of Baubau City towards Smart City, which was attended by all Baubau City SKPD, where the FGD led by the VI Region Assistant of Communication and Information (Infocom) Association of the Region VI, planned a follow up plan the development of the smart city concept in Baubau City through the issuance of a number of supporting regulations towards smart cities, this was due to the concern of OPD in innovating because there was no legal standing against the concept.

However, in its development, this concept has not been maximally carried out because the structural changes at the OPD level were also caused by a lack of joint coordination between the agencies that developed this concept. In line with this, Ojo, Curry \& Janowski (2014) stated that the main challenge of smart cities is achieving harmony between stakeholders, communities, technology infrastructure and regional agencies.

However, the current development is quite striking in terms of people's accessibility to digital content regarding the services of the Baubau City regional government. The most striking thing in the use of information technology in local government services is the development planning process. Since 2017, the Baubau City Government through BAPPEDA 
Proceeding ICOGISS 2019

Page 275-286. ISBN: 978-602-6 988-75-1

Web Jurnal Online: jurnal.unmuhjember.ac.id By: Andy Arya Maulana Wijaya; LM. Azhar Sa’ban; Sry Mayunita Collaborative Governance To Evolve Smart City In Local Governments

has developed an online development planning application, http://eplan.baubaukota.go.id/emusrenbang/.

Through this application, it can make it easier for BAPPEDA to monitor the development of murembang results from the kelurahan to the city level. This application is then given access to each musrembang facilitator to be filled in according to the results of the development consultation at various levels. With this application, it also places the city of Bali as the best development planner in Southeast Sulawesi in 2018 and 2019. The display of this application can be seen in Figures 2 and 3.

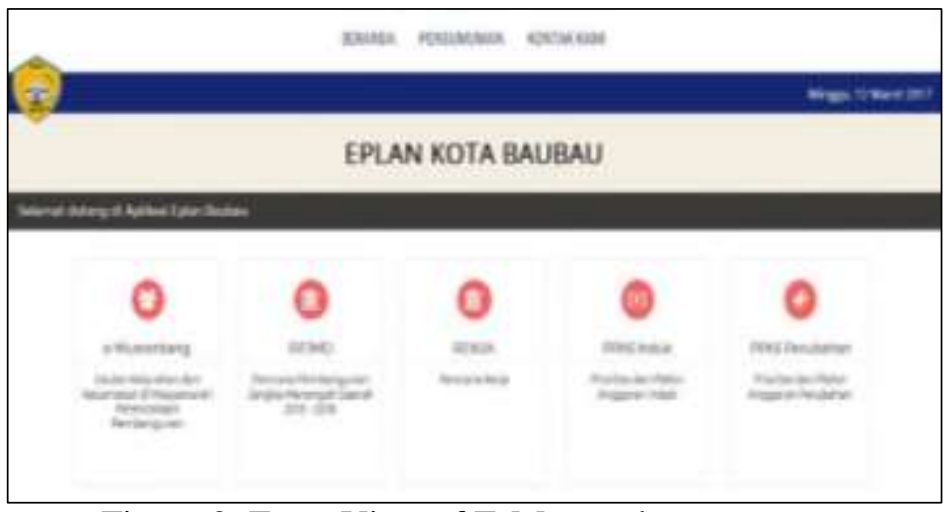

Figure 2. Front View of E-Musrembang

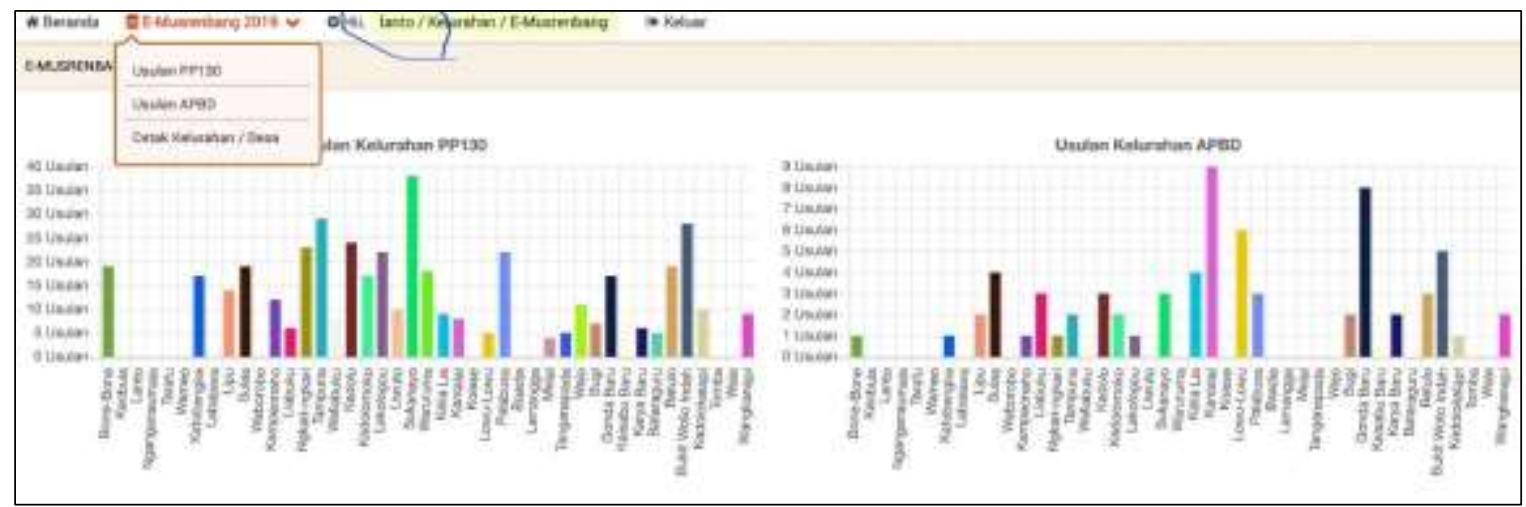

Figure 3. Display of the E-Musrembang for each proposal of the Kelurahan

The next development of this application and method is the still finding uncertainty about the sustainability of the application in the work program of the relevant agencies. Regarding these conditions, the author found various dynamics in facilitating Musrembang both at the village and sub-district levels, it was seen that there was still some lack of understanding of the OPD including the kelurahan and kecamatan government regarding the use of this application. So that Bappeda as the control holder still needs a lot of time to provide an operational explanation of the program's work system.

Emerson and Nabatchi (2015) call it a part of drivers. Where the success of a collaboration is also determined there is a common understanding between collaborative 
Proceeding ICOGISS 2019

Page 275-286. ISBN: 978-602-6 988-75-1

Web Jurnal Online: jurnal.unmuhjember.ac.id

By: Andy Arya Maulana Wijaya; LM. Azhar Sa’ban; Sry Mayunita

Collaborative Governance To Evolve Smart City In Local Governments

actors in developing digital content in government services. If at the stakeholder level the local government still has operational technical weaknesses like that, it does not rule out the possibility at the level of the city community, it will be difficult to adjust to the existing developments. This is in line with the critical note about Smart City by Harms (2016) that people will be far more difficult to be expected to participate as well as government agencies and businesses because people will be more easily contacted as groups of cucumbers as individuals.

Observing these conditions, as part of collaborative governance that the adoption of the concept of smart cities in the city of Bali is faced with several factors that influence its development, including non-technical issues such as understanding between government agencies, shared capabilities in the use of information technology (Anderson \& Pierce, 2017), and active community participation so assistance is still very much needed.

\section{b. Collaborative Governance in Understanding the Dynamics of Smart Cities in the Regional Government of the City of Baubau.}

In the conceptual framework of collaborative governance by Emerson \& Nabatchi (2015), explaining that collaborative actions are fundamentally cycle-shaped processes, interactions are carried out by improving good communication, shared understanding, principled engangement, shared motivation (shared motivation), and the capacity for joint action. To describe the process, it is necessary to analyze this action in the following sections:

1. Smart City Policy as Principled Engineering.

Challenges of the Regional Government in implementing the concept of smart cities so far local governments still use regulations related to smart cities such as Law No. 25 of 2004 concerning the National Development Planning System, Law No. 11 of 2008 concerning Information and Electronic Transactions, Law No. 14 of 2008 concerning Public Information Openness, Law No. 25/2009 concerning Public Services, and Law No. 23 of 2014 concerning Regional Government.

Regions are required to innovate in the provision of public services for their citizens as in Article 386, namely all forms of regional government reform. The definition of innovation is an idea, practice or object that is considered new by the individual. Innovations can be in the form of new products or services, new production process technology, new structures, and administration or new plans for organizational members (Suhendra, 2017).

Understanding the Principles of Management, through Mayor Baubau's Decree Number: 050/531 / IV / 2015 Concerning the Establishment of the Smart-City Development Study Preparation Team in Baubau City In 2015, it was a milestone in the development of smart cities in the city of Baubau. This is done in order to provide effective and efficient services. The Memorandum of Understanding (MOU) with the Makassar City Government may be a best practice, also online planning through e-musrembang as a form of transparency 
and accountability. But it also needs to be supported by mutual awareness and understanding of the concept of smart cities and the goals behind them.

As a think tank in regional development, Baubau City Bappeda plays a role in smart city governance that has been initiated through the legal standing. Some of the innovative products that have been made include e-plan musrembang. It's just that at the level of subdistrict and kelurahan government, this idea still cannot be implemented. Some of the problems found were lack of program coordination across sectors, urban resource capacity, and also inadequate availability of supporting infrastructure.

2. Building shared motivation

In several interviews, the public expressed their desire to participate in the development of the City. But it is difficult to get access to participatory information and doors that can be followed or is a means to be involved in ensuring the concepts of transparency, accountability, and responsibility as a manifestation of good governance in the local government in Baubau City. For this reason, smart city initiatives are needed that can lead to changes in organizational culture, and in turn, cultural changes in local government can also influence smart city initiatives (Alawdhi et al., 2012).

On the other hand, the Baubau City government also initiated multi-stakeholder involvement in programs and policy making. On several occasions government programs, policy formulation and the making of academic manuscripts, which also follow the authors involved, indicate the openness of the Baubau City government in building shared motivation with various parties. Like the statement of Bartenberger \& Grubmuller (2014) which introduces concrete and comprehensive collaborative management work through a collaborative process in the context of smart cities.

Several processes for implementing this have been carried out, although there are still some technical and non-technical deficiencies encountered. In fact, in some agencies, there are still several complaints that have been made with this innovation. Reflecting on the implementation of the Surabaya City development process towards Smart City is not sectoral, but rather a holistic approach. There are 4 phases in it, namely the internal improvement phase of the government, the phase of strengthening social capital, the development phase of government external services, and the phase of high technology-based city service development (Widyaningsih, 2013). Of course, the concept of a smart city cannot only come from the existence of a legal standing and one or two responsible institutions, but the need for collaborative synergies in this study is called multi-stakeholder.

3. Community contribution as a capacity for joint action

One of the assets possessed by the Baubau City government in developing an adaptive government to the development of the demands of society and the environment is the presence of various creative communities in the fields that participate in exploiting their potential in helping the government. On the other hand, contributive roles are also used by local governments in a number of work programs and regional policies. Where often 
Proceeding ICOGISS 2019

Page 275-286. ISBN: 978-602-6 988-75-1

Web Jurnal Online: jurnal.unmuhjember.ac.id

By: Andy Arya Maulana Wijaya; LM. Azhar Sa’ban; Sry Mayunita

Collaborative Governance To Evolve Smart City In Local Governments

community communities are involved in the formulation of policies to technical operations in the community.

In addition, the climate of regional government is still providing support for innovations from the community. Even though on several occasions this has not yet given the government partisanship to the community. In the author's observation, the development of digital content originating from the community continues to grow from year to year. Community involvement in several government programs also stands out, such as the development of creative enterprises, tourism, education, and youth. Even though it needs to be recognized that the presence of regional governments in the form of material support and legal standing is still considered weak.

In the author's observations, this community is engaged in various fields such as the environmental field by the Baubau Green Volunteers, the Field of Education by the Sekolah Jelajah Dunia, Rumah Kreatif, while the Creative Economy Sector have Baubau Creative Forum, ICCN to other creative groups. On the other hand, as the field of use of digital technology has also been found by the creative community of the video sector, photography and most recently the presence of local online transportation applications with a brand named Kururio. In addition, local governments also need to pay attention to tourism promotions carried out by various communities, in their own creative ways and methods.

This condition can actually be seen as a challenge and an opportunity for local governments to provide space in a collaborative scheme for the community in supporting a number of government programs. At least, collaborative implementation can provide community opportunities to support the development of government services that are still lacking, due to various technical issues such as resources and funding of activities.

With these dynamics, the Baubau City regional government needs protection from its innovative community activities. In addition, there needs to be an effort to spur regional creativity to improve regional competitiveness, and need objective criteria so that it can be used as a guide for local officials to carry out innovative candidate activities to the lowest level of government in Baubau City.

In the end, the concept of a smart city just not only rely on technology in an effort to provide good public services for the public. However, the effectiveness of local government in managing various local resources to provide public services that are effective, efficient, transparent and accountable to the community. 
Proceeding ICOGISS 2019

Page 275-286. ISBN: 978-602-6 988-75-1

Web Jurnal Online: jurnal.unmuhjember.ac.id

By: Andy Arya Maulana Wijaya; LM. Azhar Sa'ban; Sry Mayunita

Collaborative Governance To Evolve Smart City In Local Governments

\section{CONCLUSION}

To apply the concept of a smart city, we need a similar paradigm for all stakeholders in the region. Likewise, the Baubau City government, as the leading sector in the application of the concept of a true city of collaboration, is created in a climate of good cooperation among parties who want to prioritize innovation as a form of public service to the public. The Baubau City Government has a set of rules to support the creation of a smart city, Bappeda is the coordinator in an effort to realize the concept of Smart Cities.

However, a number of challenges in its implementation were also found, including there was still a lack of coordination between sectors, still lack the infrastructure to the level of the kelurahan government, competency in human resources. However, in the collaborative governance scheme for the development of the concept of smart cities in the City of Baubau, it has opportunities with the presence of the community in various fields of participation to have a positive impact on the region. For this reason, this study considers that the concept of smart cities is not only an advantage in using information technology in the provision of public services but the ability of local governments to use local resources effectively to help provide sustainable public services to their communities. 
Proceeding ICOGISS 2019

Page 275-286. ISBN: 978-602-6 988-75-1

Web Jurnal Online: jurnal.unmuhjember.ac.id

By: Andy Arya Maulana Wijaya; LM. Azhar Sa'ban; Sry Mayunita

Collaborative Governance To Evolve Smart City In Local Governments

\section{BIBLIOGRAPHY}

Alawadhi, S., Aldama-Nalda, A., Chourabi, H., Gil-Garcia, J. R., Leung, S., Mellouli, S., ... \& Walker, S. (2012, September). Building understanding of smart city initiatives. In International Conference on Electronic Government (pp. 40-53). Springer, Berlin, Heidelberg.

Anderson, B.,\& Pierce, P. (2017). Challenges with smart cities initiatives - A municipal decision makers perspective. HICSS.

Ansell C \& Gash A. (2008). Collaborative Governance in Theory and Practice. In J. Public Administration Research and Theory, 18 (4): 543-571. Advance Access published online Nov 13, p1. doi:10.1093/jopart/mum032

Bartenberger, M., \& Grubmüller, V. (2014). The enabling effects of open government data on collaborative governance in smart city contexts.

Berg, B. L. (2001). Qualitative Research Methods For The Social Sciences. (Sarah L. Kelbaugh, Ed.) (4th ed.). United State of Amerika: California State University

Chourabi, H., Nam, T., Walker, S., Gil-Garcia, J. R., Mellouli, S., Nahon, K., ... \& Scholl, H. J. (2012, January). Understanding smart cities: An integrative framework. In System Science (HICSS), 2012 45th Hawaii International Conference on (pp. 2289-2297). IEEE.

Emerson, K., \& Nabatchi, T. (2015). Collaborative governance regimes. Georgetown University Press.

Griffinger, R., dkk (2007). Smart cities Ranking of European medium-sized cities. Final report October

Harms, J. R. (2016, July). Critical Success Factors for a Smart City Strategy. In Proceedings of 25th Twente Student Conference on IT (July 1, 2016).

Ojo, A., Curry, E., \& Janowski, T. (2014). Designing next generation smart city initiativesharnessing findings and lessons from a study of ten smart city programs.

Pratiwi, A. (2015). Tingkat Kesiapan Kota Surakarta terhadap Dimensi Mobilitas Cerdas (Smart Mobility) sebagai Bagian dari Konsep Kota Cerdas (Smart City).

Rohman, Ainur.,et.al. (2012). Partisipasi warga dalam Pembangunan dan Demokrasi, Malang: Program Sekolah Dem okrasi bekerjasama dengan Averros Press.

Rosalina, V., Sugiyani, Y., \& Triayudi, A. (2017). Perancangan Infrastruktur Jaringan Komputer Dalam Konsep Membangun Serang Menuju Smart City. Prosisko: Jurnal Pengembangan Riset dan Observasi Sistem Komputer, 1. 
Proceeding ICOGISS 2019

Page 275-286. ISBN: 978-602-6 988-75-1

Web Jurnal Online: jurnal.unmuhjember.ac.id

By: Andy Arya Maulana Wijaya; LM. Azhar Sa’ban; Sry Mayunita Collaborative Governance To Evolve Smart City In Local Governments

Sariffuddin, S. (2015). Peluang Pengembangan Smart City untuk mewujudkan Kota Tangguh di Kota Semarang; Studi Kasus Penyusunan Sistem Peringatan Dini Banjir Sub Drainase Beringin., Jurnal Teknik Undip, 36 (1), 2015, 32 - 38.

Silvia, Chris. (2011). Collaborrative Governance Concepts for Succesful Network Leadership. State and Local Government Review from SAGE Publication, Vol. 43 (1), hal. 66-71

Suhendra, A. (2017). Kesiapan Pemerintah Daerah dalam Mewujudkan Kota Cerdas di Bandung dan Surabaya. Matra Pembaruan: Journal of Policy Innovation, 1(1), 1-9.

Widyaningsih, D., \& Djunaedi, I. A. (2013). Kota Surabaya Menuju Smart City (Doctoral dissertation, Universitas Gadjah Mada).

Yin, R. K. (2009). Case Study Research: Design and Methods. Applied social research methods series; (Fourth, Vol. 5.). London: SAGE Publications Inc.http://doi.org/10.1097/FCH.0b013e31822dda9e. 